\title{
Are modern dairy cows suffering from modern diseases?
}

\author{
Lijden moderne melkkoeien aan welvaartsziekten?
}

\author{
J. De Koster, G. Opsomer \\ Department of Reproduction, Obstetrics and Herd Health \\ Faculty of Veterinary Medicine, Ghent University \\ Salisburylaan 133, 9820 Merelbeke \\ jenne.dekoster@Ugent.be
}

\begin{abstract}
Overconditioning at calving is one of the most important risk factors for modern dairy cows to develop diverse health problems during the transition period. Currently, the metabolic syndrome gains much attention in human medicine. Research shows that the adipose tissue itself plays a crucial role in the increased susceptibility of obese people to a range of health problems, with cardiovascular disease and type 2 diabetes mellitus as the most important problems. The purpose of the present paper is to describe the human metabolic syndrome and the fat cow syndrome with emphasis on both the similarities and differences. It may lead to a better understanding of the pathophysiology of the fat cow syndrome, giving rise to innovative insights into how to improve the management of modern dairy cows in the transition period.
\end{abstract}

\section{SAMENVATTING}

Vervetting rond het moment van afkalven leidt bij melkkoeien vaak tot het ontstaan van het fat cow syndrome en is een van de belangrijkste risicofactoren voor de ontwikkeling van gezondheidsproblemen bij deze koeien gedurende de transitieperiode. Tegenwoordig wordt in de humane geneeskunde heel wat onderzoek verricht naar de pathofysiologie van het zogenaamde metabool syndroom. Uit het onderzoek blijkt dat het vetweefsel van obese mensen een cruciale rol speelt in de verhoogde gevoeligheid voor de ontwikkeling van verschillende gezondheidsproblemen, waarvan cardiovasculaire aandoeningen en type 2 diabetes mellitus de belangrijkste zijn. Het doel van dit artikel is om het humaan metabool syndroom en het fat cow syndrome te beschrijven met de nadruk op de gelijkenissen en de verschillen tussen beide aandoeningen. Dit kan leiden tot de ontwikkeling van nieuwe inzichten in de pathofysiologie van het fat cow syndrome en aldus tot een verbetering van het management van de moderne melkkoe gedurende de transitieperiode teneinde de gezondheidstoestand van de dieren te optimaliseren.

\section{INTRODUCTION}

Nowadays, dairy cows are capable of producing enormous amounts of milk. From 1950 till now, milk production has nearly quadrupled. This high level of milk production is mainly enabled by a long-time genetic selection towards higher milk production. However, the expression of this genetic potential is only fully achieved when the cows are managed under optimal conditions. Deviations from these optimal conditions easily result in an increased risk to develop health problems, especially during the immediate postpartum period.

Overconditioning at calving is one of the most important risk factors for modern dairy cows to develop a range of health problems during the transition period (Roche et al., 2009). The fat cow syndrome was first described by Morrow (1976) as a combination of metabolic, digestive, infectious and reproductive disorders that affects obese periparturient dairy cows.

Currently, a very similar syndrome receives attention in human medicine mainly affecting obese people and rendering them more susceptible to a range of health problems, with cardiovascular disease and type 2 diabetes mellitus as the most important diseases. The syndrome has been named the metabolic syndrome, and was formerly known as 'the deadly quartet' and 'syndrome X' (Cornier et al., 2008). The adipose tissue of these obese patients seems to play a central role in the pathophysiology of the syndrome by producing several bioactive molecules, also known as adipokines (Hutley and Prins, 2005).

The detrimental effects of obesity are not limited to cows and humans. Obesity has been assigned as an important risk factor for the development of non-communicable diseases in different species. Obese dogs and cats have a shorter life expectancy and are at increased risk to develop diabetes mellitus, neoplasia, cardio-respiratory, gastro-intestinal, orthopedic and urogenital disorders (German et al., 2010; Zoran, 2010). In horses, there is an important relationship between obesity and the development of insulin resistance and laminitis (Geor, 2008; Frank, 2009). Postpartum dysgalactia in sows has been associated with different risk 
factors. One of these risk factors is the overconditioning at parturition (Maes et al., 2010). In accordance with the human metabolic syndrome, it is supposed that the adipose tissue provokes a derailment of the normal physiological processes in obese animals, thereby rendering them more susceptible to different health problems.

The purpose of the present paper is to describe the human metabolic syndrome and the fat cow syndrome with emphasis on both the similarities and differences.

\section{THE HUMAN METABOLIC SYNDROME}

\section{Situation and importance}

The increasing prevalence of obesity is an important health concern for the modern human population. The World Health Organization (WHO) estimated that in 2008 at least 500 million adults were obese (body mass index or BMI $>30$ ), whereas 1,5 billion adults were overweight $(\mathrm{BMI}>25)$. Simultaneously, the prevalence of several obesity associated diseases, such as type 2 diabetes mellitus and cardiovascular disease, is increasing. A special term has been created to identify obese people who are at high risk to develop type 2 diabetes mellitus and cardiovascular disease. This term is called the metabolic syndrome (Cornier et al., 2008). The metabolic syndrome was defined by the International Diabetes Federation (IDF): 'for a person to be defined as having the metabolic syndrome, he or she must have:

- central obesity (waist circumference $\geq 94 \mathrm{~cm}$ for European men and $\geq 80 \mathrm{~cm}$ for European women)

- plus two of the following four factors:

- raised triglyceride level (>150 mg/dl)

- reduced HDL (high density lipoprotein) cholesterol $(<40 \mathrm{mg} / \mathrm{dl}$ for men and $<50 \mathrm{mg} / \mathrm{dl}$ for women)

- raised blood pressure (systolic blood pressure $\geq$ $130 \mathrm{~mm} \mathrm{Hg}$ or diastolic blood pressure $\geq 85 \mathrm{~mm}$ $\mathrm{Hg})$

- raised fasting plasma glucose $(\geq 100 \mathrm{mg} / \mathrm{dl})$ or previously diagnosed type 2 diabetes mellitus' (International Diabetes Federation, 2006).
The IDF estimates that $20-25 \%$ of the adult world population can be classified as suffering from the metabolic syndrome (International Diabetes Federation, 2006). Besides cardiovascular disease and type 2 diabetes mellitus, other conditions associated with obesity and the metabolic syndrome are non-alcoholic fatty liver disease, the polycystic ovarian syndrome, obstructive sleep apnea, hypogonadism, microvascular disease, immune dysfunction and periodontitis (Marti et al., 2001; Cornier et al., 2008; Bullon et al., 2009).

At present, much attention is given to the role of the adipose tissue in these obesity associated diseases, with special emphasis on adipokines, non-esterified fatty acids (NEFA's), metaflammation (= a form of chronic, low-level systemic inflammation, being linked to the metabolic syndrome) and abdominal obesity (Hotamisligil, 2006; Cornier et al., 2008; Després and Lemieux, 2006; Lafontan and Berlan, 2003).

\section{Adipokines}

Research on the role of adipose tissue in the pathogenesis of the metabolic syndrome has revealed that the adipose tissue is capable of secreting a wide range of different proteins, called adipokines (Pittas et al., 2004).

Up till now, more than 50 different adipokines have been identified (Trayhurn and Wood, 2005). These adipokines act locally (autocrine effect) or are secreted in the peripheral circulation to have endocrine effects (Prins, 2002). The adipose tissue of obese people produces more pro-inflammatory adipokines (TNF- $\alpha$, IL6, leptin, monocyte chemoattractant protein-1 or MCP-1) and less anti-inflammatory adipokines (adiponectin). The most important consequences of the altered secretion of adipokines, as seen in obesity, are the induction of a pro-inflammatory state, cardiovascular damage and insulin resistance of the adipose tissue, the liver and the skeletal muscle (Cornier et al., 2008) (Table 1).

\section{The pro-inflammatory state}

Due to the altered production of adipokines, obese people are considered to be in a pro-inflammatory state with the adipose tissue itself as the primary site of inflammation (Gustafson et al., 2007). This chronic pro-inflammatory state is sometimes referred to as a

Table 1. List of the most important adipokines with their potential effects (Guerre-Millo, 2004; Meier and Gressner, 2004; Wozniak et al., 2009).

\begin{tabular}{cc}
\hline Adipokine & Potential effects \\
\hline Leptin & $\downarrow$ food intake, $\uparrow$ energy expenditure, \\
Adiponectin & $\uparrow$ insulin sensitivity, pro-inflammatory \\
& $\uparrow$ insulin sensitivity, anti-inflammatory, \\
Resistin & anti-atherogenic \\
& pro-inflammatory, $\downarrow$ insulin sensitivity in rodents \\
(effect in humans not clearly identified) & $\downarrow$ insulin sensitivity, pro-inflammatory \\
TNF- $\alpha$ (Tumor necrosis factor $\alpha)$ & $\downarrow$ insulin sensitivity, pro-inflammatory \\
IL-6 (Interleukin 6$)$ & \\
\end{tabular}




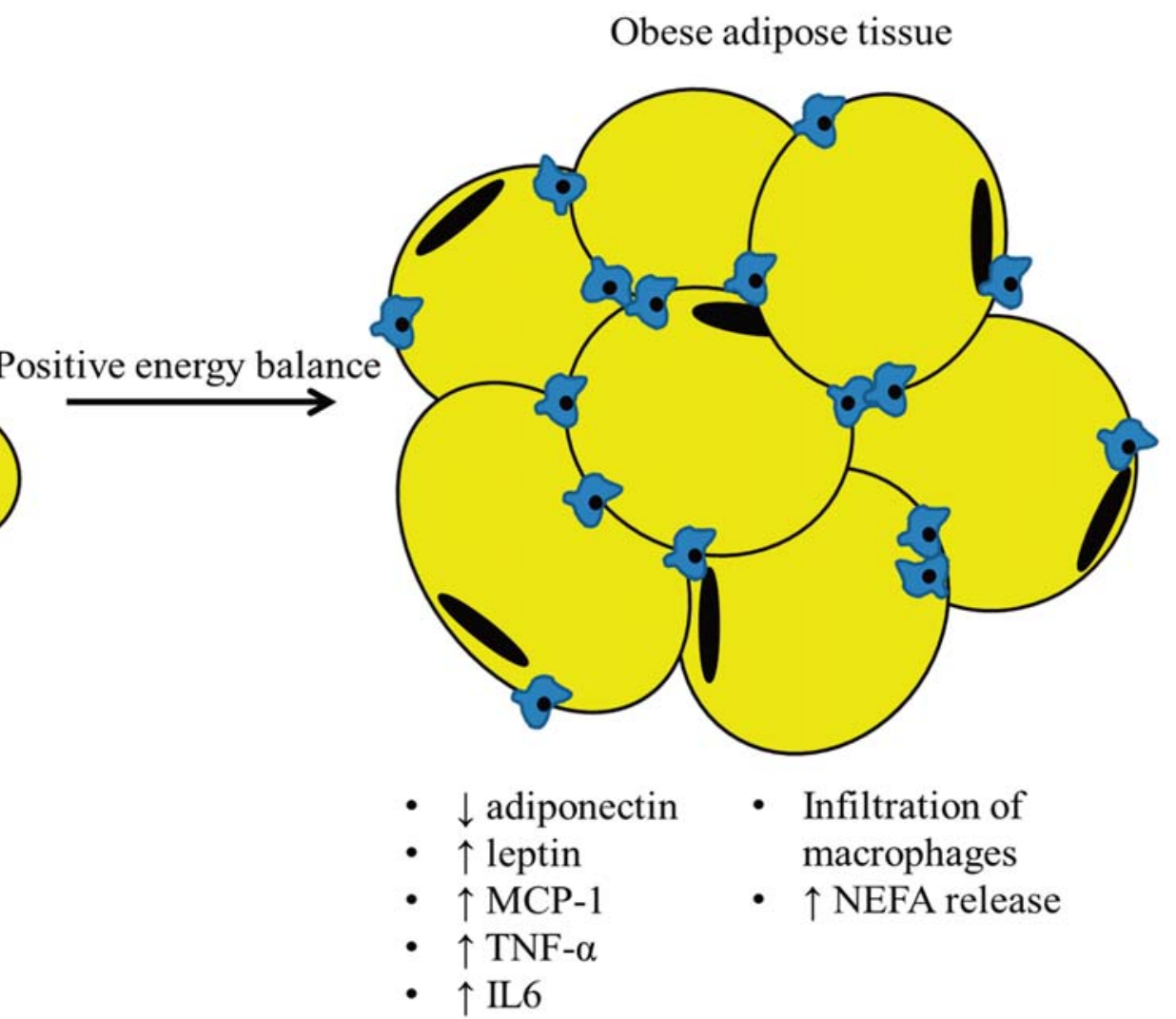

Figure 1. When the adipose tissue becomes 'obese', macrophages infiltrate the adipose tissue. Additionally, the adipose tissue releases more NEFA's and inflammatory adipokines, whereas the secretion of anti-inflammatory adipokines (adiponectin) decreases (Gustafson et al., 2007).

'metaflammation' or metabolically triggered inflammation (Hotamisligil, 2006). The adipose tissue becomes inflamed when an excessive amount of triglycerides are stored in the adipocytes. Enlarged adipocytes react to this stress by producing more pro-inflammatory adipokines and less anti-inflammatory adipokines. This results in an infiltration of macrophages in the adipose tissue, which contributes to the production and secretion of pro-inflammatory proteins (Cancello and Clément, 2006; Gustafson et al., 2007) (Figure 1). In addition, some of the hypertrophic adipocytes become necrotic, which enhances a further infiltration of macrophages (Cinti et al., 2005).

The increased concentration of circulating NEFA as typically observed during obesity contributes to the production of pro-inflammatory adipokines by activating the inflammatory pathways in both adipocytes and macrophages (Shi et al., 2006).

Interestingly, the pro-inflammatory state associated with obesity increases the susceptibility to various infections in obese people and animals (Dixit, 2008). In obese dogs, mortality due to canine distemper virus has been shown to be significantly increased (Bresnahan and Newberne, 1968), while obese mice display a six fold increase in mortality due to influenza virus infection (Smith et al., 2007). However, the exact mechanism by which obesity induces a pro-inflammatory impaired immune status, is not yet fully elucidated.

\section{NEFA}

Besides the altered production of adipokines, the obese body is also exposed to an elevated concentration of circulating NEFA (Lewis et al., 2002). NEFA have direct and indirect effects on the health state of the obese person: indirectly by stimulating the production of adipokines, and directly by inducing insulin resistance at the liver (increased gluconeogenesis), the skeletal muscle (decreased glucose uptake) and the adipose tissue (decreased glucose uptake and decreased inhibition of lipolysis by insulin) (Shi et al., 2006; Jensen, 2006a; Lewis, 2002; Van Epps-Fung et al., 1997). Chronic exposure of the pancreas to high NEFA concentrations results in an impaired insulin secretion by the $\beta$-cells (Jensen, 2006a). These alterations contribute to the development of type 2 diabetes mellitus, further harming the general health status of the obese patient (Defronzo, 2004; Kahn et al., 2006).

\section{Central or abdominal obesity}

Basically, obese people can be divided into two groups based on the location of fat accumulation. Some people accumulate fat subcutaneously, mainly around the hips and the lower part of the abdomen. This form of obesity is called peripheral obesity. People suffering from this type of fat accumulation are often referred to as 'the pears', as their overall body shape has taken the form of a pear. Others however accumulate fat subcu- 
taneously at the upper part of the abdomen and in the visceral depots (omentum, mesenterium). The latter form of obesity is called central or abdominal obesity. People suffering from this type of fat accumulation are referred to as 'the apples' (Lafontan and Berlan, 2003).

This distinction is of clinical importance because especially the accumulation of visceral fat is associated with an increased risk for obesity associated diseases, whereas this is less the case for the accumulation of subcutaneous fat (Arner, 1998; Lafontan and Berlan, 2003). This is also the reason why in the definition of the metabolic syndrome as stated by the IDF (2006), waist circumference is included in favor of the body mass index (BMI) as waist circumference reflects much better the accumulation of fat in the abdomen. There are ethnicand sex-specific cut off values for this parameter, indicating that the location where obese people store their excessive amounts of fat, is both gender and race dependent (IDF, 2006). It is generally known that men are more at risk to acquire the apple like body shape when they become obese, while obese women are more likely to become pear like (Arner, 1997).

There are some important functional differences between these two forms of obesity. The visceral adipose tissue has a higher lipolytic activity than the subcutaneous adipose tissue. This is caused by a higher lipolytic effect of catecholamines and a lower antilipolytic effect of insulin at the visceral fat cells. The resulting higher NEFA concentration in the vena porta can lead to the development of hepatic insulin resistance (Arner, 1998; Lafontan and Berlan, 2003; Jensen, 2006b). Hepatic insulin resistance, characterized by an increased gluconeogenesis, is a major contributor to the development of type 2 diabetes mellitus (Scheen, 2003).

Besides the higher lipolytic activity of the abdominal fat depots in abdominally obese persons, the production of adipokines is also different in the visceral adipocytes. In central obesity, the circulating concentration of adiponectin, an anti-inflammatory adipokine, is decreased, whereas the expression and production of proinflammatory adipokines, like TNF- $\alpha$ and IL6, are elevated in comparison to those in peripherally obese persons (Després and Lemieux, 2006). These factors in combination with the more direct contact between the visceral fat depots and the liver, generally renders abdominally obese patients more susceptible to severe health problems than peripherally obese people.

\section{THE FAT COW SYNDROME}

\section{Situation and importance}

The fat cow syndrome was first described by Morrow (1976) as a combination of metabolic, digestive, infectious and reproductive disorders that affects the obese periparturient dairy cow.

Overconditioned cows have a reduced appetite and therefore a lower dry matter intake (DMI) prepartum and a slower increase in postpartum DMI (Grummer et al., 2004). As a consequence of this reduced DMI, overconditioned cows start lactation in a more severe negative energy balance (NEB) than their normal conditioned counterparts (Grummer et al., 2004).

Additionally, the adipose tissue of overfed cows tends to be more sensitive to lipolytic and less sensitive to antilipolytic stimuli (Rukkwamsuk et al., 1998). The combination of a more severe NEB and a higher lipolytic activity of the adipose tissue results in an excessive mobilization of NEFA in the overconditioned periparturient dairy cow. A large proportion of the circulating NEFA is taken up by the liver and is metabolized in three ways: complete oxidation, partial oxidation (ketogenesis) or re-esterification (Herdt, 2000; Drackley et al., 2005). Firstly, the NEFA can be completely oxidized in the Krebs cycle with the production of carbon dioxide and energy (ATP). For this reaction, the hepatocytes need oxaloacetate. In periods of NEB and high glucose requirements (late pregnancy, lactation), the precursor molecules for this oxaloacetate are limited and the available oxaloacetate is preferentially used as substrate for the gluconeogenesis. If the mobilized NEFA are not completely oxidized, they are redirected to other metabolic pathways (Bell and Bauman, 1997; Bossaert et al., 2008b; Rukkwamsuk et al., 1999a). Secondly, the NEFA can be partially oxidized with the production of acetyl coenzyme A. This acetyl coenzyme $\mathrm{A}$ is the precursor for the ketone bodies, acetoacetate, $\beta$-hydroxybutyrate and aceton (Herdt, 2000; Bossaert et al., 2008b). Excessive production of ketone bodies results in the development of (sub)clinical ketosis. Thirdly, the hepatocytes can re-esterify the NEFA with the production of triglycerides. These triglycerides are secreted in the blood in very low density lipoproteins (VLDL), which consist of apoprotein B, triglycerides, cholesterol, cholesterol-esters and phospholipids. When the increased hepatic production of triglycerides exceeds the hepatic synthesis of very low density lipoproteins (VLDL), triglycerides are stored in the parenchyma of the liver, which leads to hepatic lipidosis or fatty liver (Rukkwamsuk et al., 1999a; Herdt, 2000; Bossaert et al., 2008a).

This is the well-known story of how a fat cow develops fatty liver and ketosis. With the current knowledge of the role of the adipose tissue in the development of obesity associated diseases in human medicine, we can no longer ignore a possible role of the endocrine function of the adipose tissue in the development of the fat cow syndrome.

\section{Comparison between the human metabolic syn- drome and the fat cow syndrome}

When comparing the human metabolic syndrome with the fat cow syndrome, it is clear that there are a lot of similarities: overconditioned cows are insulin resistant (McCann and Reimers, 1985; Holtenius and Holtenius, 2007), the adipose tissue of dairy cows is also capable of producing different adipokines (Ingvartsen and Boisclair, 2001; Komatsu et al., 2003; Ko- 
matsu et al., 2005; Lemor et al., 2009; Mukesh et al., 2010; Sadri et al., 2010), the disease susceptibility of dairy cows is associated with a pro-inflammatory state (Ohtsuka et al., 2001; Ametaj et al., 2005; Bertoni et al., 2008; Bradford et al., 2009), the immunity of overconditioned cows is attenuated (Lacetera et al., 2005), and overconditioned dairy cows are overall more susceptible to a variety of diseases (Morrow, 1976).

Apart from these similarities, there are some important differences between both syndromes. In human medicine, obesity is associated with insulin resistance (normoglycemia and secondary hyperinsulinemia) or type 2 diabetes mellitus (hyperglycemia). Due to the special carbohydrate metabolism in lactating dairy cows, the glucose and insulin concentrations during early lactation are low due to the high loss of glucose through the production of milk (Herdt, 2000) (Table 2).

\section{NEFA in dairy cows}

The physiological and pathological role of NEFA in dairy cattle is well-studied. Triglycerides are the most important energy reserve and are mobilized as NEFA during NEB (Herdt, 2000). As long as the NEFA release from the adipose tissue is limited, this can be seen as favorable since NEFA can directly or indirectly (as ketone bodies) be used as energy substrate in different tissues, thereby sparing glucose for milk production.
However, excessive fat mobilization results in an overload of NEFA with a negative impact on the production, reproduction and insulin sensitivity (Pires et al., 2007; Bossaert et al., 2008c).

Especially in ruminants, an overload of NEFA easily surpasses the liver's capacity to produce apoprotein B and VLDL. This leads to an increased amount of triglycerides, being accumulated in the hepatocytes (Gruffat et al., 1996). This fatty infiltration of the liver impairs the hepatic metabolism, which results in a reduced activity of gluconeogenic enzymes (Rukkwamsuk et al., 1999b). Since in cattle, the liver is the primary site of glucose production, the reduced gluconeogenic activity results in a decreased glucose production and a reduced milk production.

Research at our department furthermore revealed that high circulating concentrations of NEFA may reach the follicular fluid in the ovary and have a detrimental effect on the oocyte quality, which leads to poor in vitro results regarding maturation, fertilization, cleavage rate and blastocyst yield (Leroy et al., 2005).

Additionally, overconditioned cows are more insulin resistant than normal-conditioned cows (McCann and Reimers, 1985; Holtenius and Holtenius, 2007). Because overconditioned cows have a higher NEFA blood concentration, a causative role is expected for NEFA (Pires et al., 2007).

Table 2. Comparison of the human metabolic syndrome and the fat cow syndrome $(\uparrow=$ increased; $\downarrow=$ decreased; ? $=$ unknown).

\begin{tabular}{|c|c|c|c|}
\hline Property & Human metabolic syndrome & Fat cow syndrome & References \\
\hline Disease susceptibility & $\uparrow$ & $\uparrow$ & $\begin{array}{l}\text { Cornier et al. }(2008) \\
\text { Morrow (1976) }\end{array}$ \\
\hline $\begin{array}{l}\text { Adipokine } \\
\text { production }\end{array}$ & $\begin{array}{c}\uparrow \\
\text { (except } \downarrow \text { adiponectin) }\end{array}$ & $\begin{array}{c}? \\
\text { (except } \uparrow \text { leptin and } \\
\text { TNF- } \alpha \text { ) }\end{array}$ & $\begin{array}{c}\text { Cornier et al. (2008) } \\
\text { Ingvartsen and Boisclair (2001) } \\
\text { O'Boyle et al. (2006) }\end{array}$ \\
\hline Inflammation & $\uparrow$ & $\uparrow$ & $\begin{array}{l}\text { Gustafson et al., (2007) } \\
\text { Ametaj et al., (2005) } \\
\text { O’Boyle et al., (2006) }\end{array}$ \\
\hline Immune function & $\downarrow$ & $\downarrow$ & $\begin{array}{c}\text { Dixit (2008); } \\
\text { Lacetera et al., (2005) }\end{array}$ \\
\hline Insulin sensitivity & $\downarrow$ & $\downarrow$ & $\begin{array}{c}\text { Cornier et al. (2008) } \\
\text { McCann and Reimers (1985) }\end{array}$ \\
\hline $\begin{array}{l}\text { Basal insulin } \\
\text { concentration }\end{array}$ & Normal or $\uparrow$ & Normal (low) & Defronzo (2004), Herdt (2000) \\
\hline $\begin{array}{l}\text { Glucose stimulated } \\
\text { insulin response }\end{array}$ & Normal, $\uparrow$ or $\downarrow$ & $?$ & Defronzo (2004) \\
\hline Glucose concentration & $\uparrow$ or normal & Normal (low) & Defronzo (2004), Herdt (2000) \\
\hline Obesity & Visceral & $?$ & Després and Lemieux (2006) \\
\hline
\end{tabular}




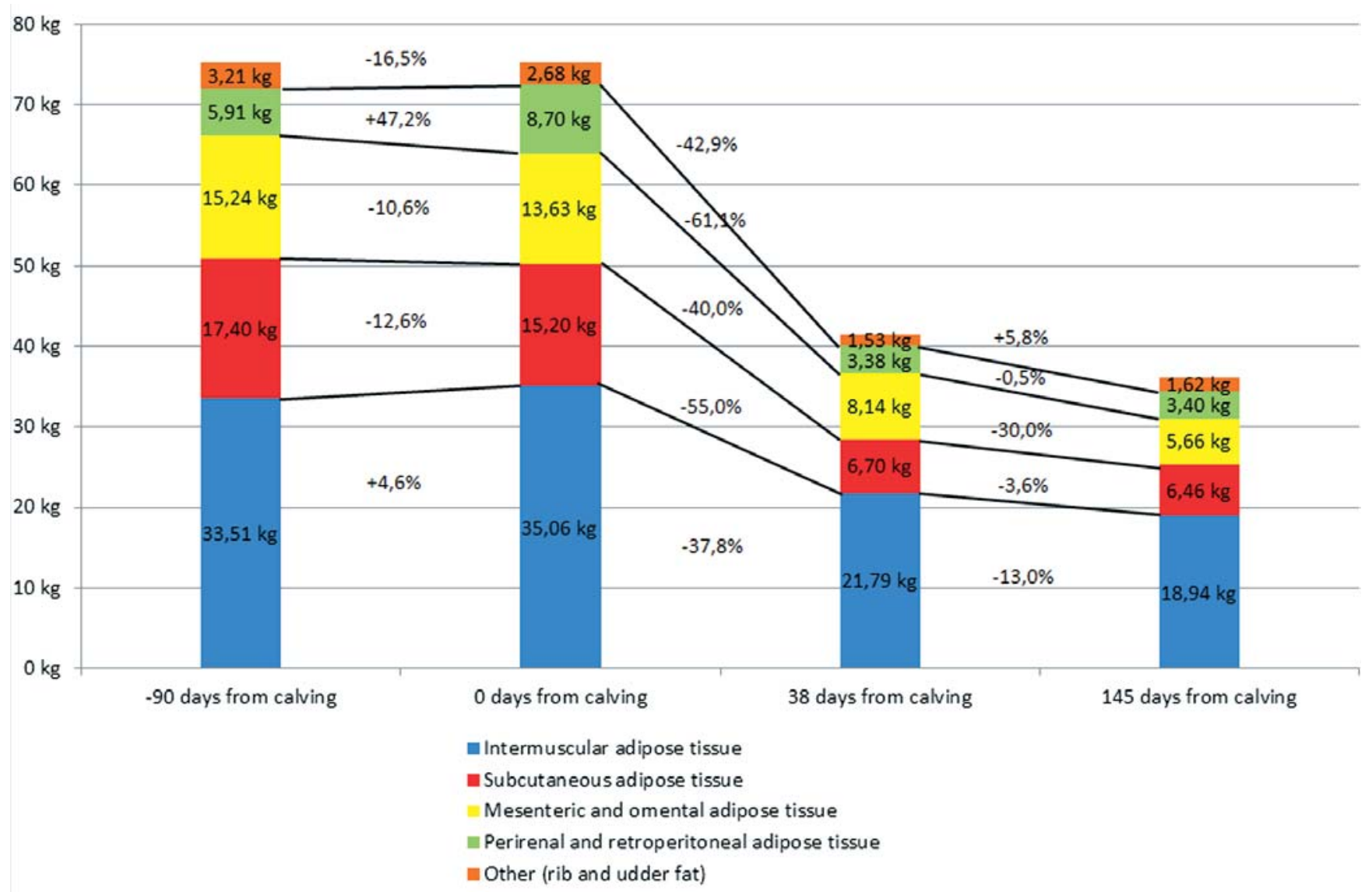

Figure 2. Average amount (in $\mathrm{kg}$ ) of fat in the different fat depots of dairy cows slaughtered at different stages in the lactation cycle (four cows slaughtered per stage). Change (in \%) of the size of the different fat depots relative to the previous point in time of each individual fat depot (Butler-Hogg et al., 1985).

In vivo and in vitro research in humans and in rodents has shown that NEFA directly inhibit the insulin signaling pathway in the skeletal muscle, the liver and the adipose tissue (Boden and Shulman, 2002; Van Epps-Fung, 1997). This was confirmed by an in vivo research in dairy cows where it was demonstrated that artificial (iatrogenic) induction of elevated NEFA concentrations causes insulin resistance (Pires et al., 2007). In fact, insulin resistance entails a lower glucose uptake in the skeletal muscle and the adipose tissue. This is favorable, since it increases the glucose availability for milk production. However, the insulin mediated inhibition of the hormone sensitive lipase at the adipose tissue may be attenuated, which may result in a further increase of the NEFA levels (Pires et al., 2007).

As in humans, the secretion of insulin by the pancreas in dairy cows, sometimes seems to be seriously compromised. In a study in which cows, previously diagnosed with cystic ovarian disease, were submitted to an intraveneous glucose tolerance test, Opsomer et al. (1999) found three cystic cows that did not react with an increased insulin secretion following the administration of an intraveneous glucose bolus. In none of the matched control cows, a similar absence of insulin secretion could be detected. A similar absence of insulin secretion following the administration of a glucose bolus in dairy cows was demonstrated by Hove
(1978) in ketonemic and starved cows. Recently, Bossaert et al. (2008c) demonstrated that the insulin secretion following the administration of an intraveneous glucose bolus is negatively associated with the level of NEFA that cows had experienced in the periparturient period. This leads us to conclude that in dairy cows as well as in humans, some individuals have susceptible $\beta$-cells whose function becomes seriously depressed by chronically elevated NEFA levels. As differences in pancreatic insulin secretion following an intraveneous glucose bolus have already been demonstrated in neonatal calves, this $\beta$-cell susceptibility has been hypothesized to have a(n) (epi)genetic background (Bossaert et al., 2009).

\section{Adipokines in dairy cows}

The altered production of adipokines by the visceral fat depots seems to be the key factor in the development of health problems in abdominally obese persons.

Research towards gene expression in adipose tissue of dairy cows has confirmed the role of the adipose tissue as an endocrine organ. Different studies have demonstrated an expression of mRNA for TNF- $\alpha$, IL6, $\mathrm{MCP} 1$, leptin, adiponectin, visfatin and resistin in the adipose tissue of dairy cows (Ingvartsen and Boisclair, 2001; Komatsu et al., 2003; Komatsu et al., 
2005; Lemor et al., 2009; Mukesh et al., 2010; Sadri et al., 2010).

To the best of our knowledge, the exact function of most of the adipokines in dairy cows are unknown, except for leptin. Leptin is an important regulator of feed intake and influences the adaptational mechanisms during the transition period. However, there are also indications that leptin may influence the reproductive and immune systems (Ingvartsen and Boisclair, 2001). For leptin, it is known that the plasma concentration in dairy cows is influenced by BCS and energy balance, with a higher plasma concentration in cows with a high BCS and a lower plasma concentration during early lactation (Ingvartsen and Boisclair, 2001; Meikle et al., 2004). For adiponectin, a possible role in the adaptational mechanism is expected because of the increase in the plasma concentration during the first weeks of lactation. It reaches a maximum value at four weeks post partum. Subsequently, the value declines and remains stable from the fifth till the eleventh week post partum. In contrast with human adiponectin, in dairy cows no influence of the BCS on the plasma concentration of adiponectin can be observed. However, these values are generated using a human radioimmunoassay kit and may not accurately reflect the real plasma concentrations of adiponectin in dairy cows (Raddatz et al., 2008).

For TNF- $\alpha$, it has been demonstrated that cows with a BCS $>3.5$ tend to have a higher plasma TNF- $\alpha$ concentration than cows with a normal BCS (BCS 2.5-2.7) during mid-lactation (O'Boyle et al., 2006). Additionally, increased serum TNF- $\alpha$ concentrations have been shown to be associated with insulin resistance and the development of fatty liver (Ohtsuka et al., 2001; Bradford et al., 2009).

\section{The pro-inflammatory state in dairy cows}

A recent study in dairy cows demonstrated a negative correlation between sustained low plasma concentration of negative acute phase proteins during lactation and health and fertility problems (Bertoni et al., 2008). The cows with chronically low concentrations of negative acute phase proteins, as measured by the average plasma concentration of albumin, cholesterol and retinol-binding protein at 7, 14 and 28 days in milk (DIM), had also the highest plasma concentration of haptoglobin, a positive acute phase protein. The cows with chronically low concentrations of negative acute phase proteins had a higher frequency of health (dystocia, milk fever, retained placenta, ketosis, lameness, mastitis) and fertility problems (Bertoni et al., 2008). Other studies confirm these observations by demonstrating a strong positive correlation between positive acute phase proteins and cytokines and the development of fatty liver post partum (Ohtsuka et al., 2001; Ametaj et al., 2005; Bradford et al., 2009).

These data suggest a role for chronic low-grade inflammation in several diseases that occur during the transition period.

\section{Immune function and overconditioning in dairy cows}

The association between overconditioning and the elevated incidence of infectious diseases has been explained by an impaired immune function in overconditioned cows. In the periparturient period, it is observed that the lymphocyte function is attenuated in overconditioned cows (Lacetera et al., 2005). Moreover, overconditioned cows have higher circulating concentrations of reactive oxygen metabolites and lower circulating concentrations of antioxidants (Bernabucci et al., 2005). This increased oxidative stress may be an important cause of an attenuated immune function (Sordillo and Aitken, 2009).

\section{BCS and abdominal obesity}

In dairy cows, body condition scoring (BCS) and the ultrasonographic measurement of back fat thick-ness are practical methods to describe the energy reserve at a specific point in time in the lactation cycle (Schröder and Staufenbiel, 2006). By comparing the BCS of one and the same cow at different points in time, it is possible to have an idea of the energy balance over that period in that specific cow. The BCS system as used in dairy cattle is based on the subjective visual and/or tactile evaluation of the amount of subcutaneously stored fat at the lumbar, sacral and tail region (Bewley and Schutz, 2008).

The total amount of fat stored in the body of dairy cows can be divided into different fat depots dependent on the localization. The largest amount of body fat can be found intermuscularly (50\%), followed by subcutaneous fat $(15-20 \%)$, omental fat $(10 \%)$, perirenal-retroperitoneal fat $(10 \%)$, mesenteric fat $(7 \%$ $8 \%$ ) and fat stored in other parts of the body (ButlerHogg et al., 1985). Hence, by assessing the BCS, only $15-20 \%$ of the total body fat, being the subcutaneous fat, is evaluated. There is a positive correlation between the BCS, the total amount of body fat and the amount of fat stored in the individual fat depots. Nevertheless, not all fat depots are mobilized or replenished at the same time, at the same magnitude (Butler-Hogg et al., 1985). During early lactation in dairy cows, relatively more fat is mobilized from the subcutaneous and perirenal-retroperitoneal fat depots than from the intermuscular, omental and mesenteric fat depots (ButlerHogg et al., 1985) (Figure 2).

In a recent study, overfeeding non-pregnant dry Holstein cows resulted in a significant increase of omental, mesenteric and perirenal fat without changes in BCS (Nikkhah et al., 2008). This implies that a cow can have a normal body condition score even though she possesses a large amount of 'invisible' abdominal fat stored in the mesenterium and the omentum (Van Eetvelde et al., 2011). Additionally, dairy cows seem to have a genetic tendency to accumulate more fat in the intra-abdominal depot and less fat in the subcutaneous depot (Wright and Russel, 1984). In human me- 
dicine, the accumulation of fat in the abdomen is linked to an increased disease susceptibility. Whether the same holds true for dairy cows remains an open question.

\section{CONCLUSION}

The recent developments in research on the pathophysiology of the metabolic syndrome in human medicine have revealed an important endocrine function of the adipose tissue. The adipose tissue is no longer considered to be only a storage place for excess energy; it is also capable of secreting a wide array of bioactive molecules, named adipokines. These adipokines seem to be the missing link between obesity, cardiovascular disease and insulin resistance in human medicine.

In dairy cows, in which overconditioning at calving means an increased risk for reproductive, infectious and metabolic disorders in the transition period, we can no longer ignore the secretory capacity of the adipose tissue. This new perspective on the role of the adipose tissue in these disorders highlights the importance of monitoring the BCS during the lactation cycle and gives new opportunities for the treatment and management of the transition cow.

\section{REFERENCES}

Ametaj B.N., Bradford B.J., Bobe G., Nafikov R.A., Lu Y., Young J.W., Beitz D.C. (2005). Strong relationships between mediators of the acute phase response and fatty liver in dairy cows. Canadian Journal of Animal Science 85, 165-175.

Arner P. (1997). Regional adipocity in man. Journal of Endocrinology 155, 191-192.

Arner P. (1998). Not all fat is alike. The Lancet 351, 13011302.

Bell A.W., Bauman D.E. (1997). Adaptations of glucose metabolism during pregnancy and lactation. Journal of Mammary Gland Biology and Neoplasia 3, 265-278.

Bernabucci U., Ronchi B., Lacetera N., Nardone A. (2005). Influence of body condition score on relationships between metabolic status and oxidative stress in periparturient dairy cows. Journal of Dairy Science 88, 2017-2026.

Bertoni G., Trevisi E., Han X., Bionaz M. (2008). Effects of inflammatory conditions on liver activity in puerperium period and consequences for performance in dairy cows. Journal of Dairy Science 91, 3300-3310.

Bewley J.M., Schutz M.M. (2008). An interdisciplinary review of body condition scoring for dairy cattle. The Professional Animal Scientist 24, 507-529.

Boden G., Shulman G.I. (2002). Free fatty acids in obesity and type 2 diabetes: defining their role in the development of insulin resistance and $\beta$-cell dysfunction. European Journal of Clinical Investigation 32, 14-23.

Bossaert P., Cools S., Van Loo H., Leroy J., de Kruif A., Opsomer G. (2008a). De pathogenese en kliniek van ketonemie en leververvetting bij hoogproductieve melkkoeien. Vlaams Diergeneeskundig Tijdschrift 77, 283-289.

Bossaert P., Leroy J., Cools S., Van Loo H., de Kruif A., Opsomer G. (2008b). De metabole adaptatiemechanismen bij hoogproductieve melkkoeien. Vlaams Diergeneeskundig Tijdschrift 77, 207-215.
Bossaert P., Leroy J.L.M.R., De Vliegher S., Opsomer G. (2008c). Interrelations between glucose-induced insulin response, metabolic indicators and time of first ovulation in high-yielding dairy cows. Journal of Dairy Science 91, 3363-3371.

Bossaert P. Leroy J.L.M.R., De Campeneere S., De Vliegher S., Opsomer G. (2009). Differences in the glucose-induced insulin response and the peripheral insulin responsiveness between neonatal calves of the Belgian Blue, Holstein-Friesian and East Flemish breeds. Journal of Dairy Science 92, 4404-4411.

Bradford B.J., Mamedova L.K., Minton J.E., Drouillard J.S., Johnson B.J. (2009). Daily injection of tumor necrosis factor- $\alpha$ increases hepatic triglycerides and alters transcript abundance of metabolic genes in lactating dairy cattle. The Journal of Nutrition. Biochemical, Molecular and Genetic Mechanisms 139, 1451-1456.

Bresnahan M.R., Newberne P.M. (1968). Interaction of diet and distemper virus infection on lipid metabolism in the dog. British Journal of Experimental Pathology 49, 223234.

Bullon P., Morillo J.M., Ramirez-Tortosa M.C., Quiles J.L., Newman H.N., Battino M. (2009). Metabolic syndrome and periodontitis: is oxidative stress a common link? Journal of Dental Research 88, 503-518.

Butler-Hogg B.W., Wood J.D., Bines J.A. (1985). Fat partitioning in British Friesian cows: the influence of physiological state on dissected body composition. The Journal of Agricultural Science 104, 519-528.

Cancello R., Clément K. (2006). Is obesity an inflammatory illness? Role of low-grade inflammation and macrophage infiltration in human white adipose tissue. BJOG An International Journal of Obstetrics and Gynaecology, 11411147.

Cinti S., Mitchell G., Barbatelli G., Murano I., Ceresi E., Faloia E., Wang S., Fortier M., Greenberg A.S., Obin M.S. (2005). Adipocyte death defines macrophage localization and function in adipose tissue of obese mice and humans. Journal of Lipid Research 46, 2347-2355.

Cornier M., Dabelea D., Hernandez T.L., Lindstrom R.C., Steig A.J., Stob N.R., Van Pelt R.E., Wang H., Eckel R.H. (2008). The metabolic syndrome. Endocrine Reviews 29, 777-822.

Defronzo R.A. (2004). Pathogenesis of type 2 diabetes mellitus. The Medical Clinics of North America 88, 787835.Després J., Lemieux I. (2006). Abdominal obesity and metabolic syndrome. Nature 444, 881-887.

Dixit V.D. (2008). Adipose-immune interactions during obesity and caloric restriction: reciprocal mechanisms regulating immunity and health span. Journal of Leukocyte Biology $84,1-11$.

Drackley J.K., Dann H.M., Douglas G.N., Guretzky N.A.J., Litherland N.B., Underwood J.P., Loor J.J. (2005). Physiological and pathological adaptations in dairy cows that may increase susceptibility to periparturient diseases and disorders. Italian Journal of Animal Science 4, 323-344.

Frank N. (2009). Equine metabolic syndrome. Journal of Equine Veterinary Science 29, 259-267.

Geor R.J. (2008). Metabolic predispositions to laminitis in horses and ponies: obesity, insulin resistance and metabolic syndromes. Journal of Equine Veterinary Science 28, 753-759.

German A.J., Ryan V.H., German A.C., Wood I.S., Trayhurn P. (2010). Obesity, its associated disorders and the role of inflammatory adipokines in companion animals. The Veterinary Journal 185, 4-9. 
Guerre-Millo M. (2004). Adipose tissue and adipokines: for better or worse. Diabetes and Metabolism 30, 13-19.

Gruffat D., Durand D., Graulet B., Bauchart D. (1996). Regulation of VLDL synthesis and secretion in the liver. Reproduction Nutrition Development 36, 375-389.

Grummer R.R., Mashek D.G., Hayirli A. (2004). Dry matter intake and energy balance in the transition period. Veterinary Clinics of North America: Food Animal Practice 447-470

Gustafson B., Hammarstedt A., Andersson C.X., Smith U. (2007). Inflamed adipose tissue: a culprit underlying the metabolic syndrome and atherosclerosis. Arteriosclerosis, Thrombosis and Vascular Biology 27, 2276-2283.

Herdt T.H. (2000). Ruminant adaptation to negative energy balance. Influences on the etiology of ketosis and fatty liver. Veterinary Clinics of North America: Food Animal Practice 16, 215-230.

Holtenius P., Holtenius K. (2007). A model to estimate insulin sensitivity in dairy cows. Acta Veterinaria Scaninavica 49, 29-31.

Hove K. (1978). Insulin secretion in lactating cows: responses to glucose infused intravenously in normal, ketonemic and starved animals. Journal of Dairy Science 61, 14071413.

Hotamisligil G.S. (2006). Inflammation and metabolic disorders. Nature 444, 860-867.

Hutley L., Prins J.B. (2005). Fat as an endocrine organ: relationship to the metabolic syndrome. The American Journal of the Medical Sciences 330, 280-289.

Ingvartsen K.L., Boisclair Y.R. (2001). Leptin and the regulation of food intake, energy homeostasis and immunity with special focus on periparturient ruminants. Domestic Animal Endocrinology 21, 215-250.

International Diabetes Federation. (2006). The IDF consensus worldwide definition of the metabolic syndrome.

Jensen M.D. (2006a). Adipose tissue as an endocrine organ: implications of its distribution on free fatty acid metabolism. European Heart Journal Supplements 8, B13-B19.

Jensen M.D. (2006b). Is visceral fat involved in the pathogenesis of the metabolic syndrome? Human model. Obesity 14, 20S-24S.

Kahn S.E., Hull R.L., Utzschneider K.M. (2006). Mechanisms linking obesity to insulin resistance and type 2 diabetes. Nature 444, 840-846.

Komatsu T., Itoh F., Mikawa S., Hodate K. (2003). Gene expression of resistin in adipose tissue and mammary gland of lactating and non-lactating cows. Journal of Endocrinology 178, R1-R5.

Komatsu T., Itoh F., Hodate K., Hazegawa S., Obara Y., Kushibiki S. (2005). Gene expression of resistin and TNF- $\alpha$ in adipose tissue of Japanese black steers and Holstein steers. Animal Science Journal 76, 567-573.

Lacetera N., Scalia D., Bernabucci U., Ronchi B., Pirazzi D., Nardone A. (2005). Lymphocyte functions in overconditioned cows around parturition. Journal of Dairy Science 88, 2010-2016.

Lafontan M., Berlan M. (2003). Do regional differences in adipocyte biology provide new pathophysiological insights? Trens in Pharmacological Science 24, 276-283.

Lemor A., Hosseini A., Sauerwein H., Mielenz M. (2009). Transition period-related changes in the abundance of the mRNAs of adiponectin and its receptors, of visfatin, and of fatty acid binding receptors in adipose tissue of highyielding dairy cows. Domestic Animal Endocrinology 37, 37-44.

Leroy J.L.M.R., Vanholder T., Mateusen B., Christophe A.,
Opsomer G., de Kruif A., Genicot G., Van Soom A. (2005). Non-esterified fatty acids in follicular fluid of the dominant follicle in high yielding dairy cows and their effect on developmental capacity of bovine oocytes in vitro. Reproduction 130, 485-495.

Lewis G.F., Carpentier A., Adeli K., Giacca A. (2002). Disordered fat storage and mobilization in the pathogenesis of insulin resistance and type 2 diabetes. Endocrine Reviews 23, 201-229.

Maes D., Papadopoulos G., Cools A., Janssens G.P.J. (2010). Postpartum dysgalactia in sows: pathophysiology and risk factors. Tierärztliche Praxis supplement 1, S15-S20.

Marti A., Marcos A., Martinez J.A. (2001). Obesity and immune function. Obesity Reviews 2, 131-140.

McCann J.P., Reimers T.J. (1985). Glucose response to exogenous insulin and kinetics of insulin metabolism in obese and lean heifers. Journal of Animal Science 61, 612-618.

Meier U., Gressner A.M. (2004). Endocrine regulation of energy metabolism: review of pathobiochemical and clinical chemical aspects of leptin, ghrelin, adiponectin, and resistin. Clinical Chemistry 50, 1511-1525.

Meikle A., Kulcsar M., Chilliard Y., Febel H., Delavaud C., Cavestany D., Chilibroste P. (2004). Effects of parity and body condition at parturition on endocrine and reproductive parameters of the cow. Reproduction 127, 727-737.

Morrow D.A. (1976). Fat cow syndrome. Journal of dairy science 59, 1625-1629.

Mukesh M., Bionaz M., Graugnard D.E., Drackley J.K., Loor J.J. (2009). Adipose tissue depots of Holstein cows are immune responsive: inflammatory gene expression in vitro. Domestic Animal Endocrinology 38, 168-178.

Nikkhah A., Loor J.J., Wallace R.L., Graugnard D., Vasquez J., Richards B., Drackley J.K. (2008). Moderate excesses of dietary energy markedly increase visceral adipose tissue mass in non-lactating dairy cows. Journal of Dairy Science 9, E-suppl. 1.

O’Boyle N., Corl C.M., Gandy J.C., Sordillo L.M. (2006). Relationship of body condition score and oxidant stress to tumor necrosis factor expression in dairy cattle. Veterinary Immunology and Immunopathology 113, 297-304.

Ohtsuka H., Koiwa M., Hatsugaya A., Kudo K., Hoshi F., Itoh N., Yokota H., Okada H., Kawamura S. (2001). Relationship between serum TNF activity and insulin resistance in dairy cows affected with naturally occurring fatty liver. The Journal of Veterinary Medical Science 63, 1021-1025.

Opsomer G., Wensing Th., Laevens H., Coryn M., de Kruif A. (1999). Insulin resistance: the link between metabolic disorders and cystic ovarian disease in high yielding dairy cows? Animal Reproduction Science 56, 211-222.

Pires J.A.A., Souza A.H., Grummer R.R. (2007). Induction of hyperlipidemia by intravenous infusion of tallow emulsion causes insulin resistance in holstein cows. Journal of Dairy Science 90, 2735-2744.

Pittas A.G., Joseph N.A., Greenberg A.S. (2004). Adipocytokines and insulin resistance. The Journal of Clinical Endocrinology and Metabolism 89, 447-452.

Prins J.B. (2002). Adipose tissue as an endocrine organ. Best Practice and Research Clinical Endocrinology and Metabolism 16, 639-651.

Raddatz J.R., Elias A.N., Whisnant C.S. (2008). Measurement of adiponectin in lactating dairy cows. Journal of Dairy Science 91, E-suppl. 1.

Roche J.R., Friggens N.C., Kay J.K., Fisher M.W., Stafford K.J., Berry D.P. (2009). Invited review: Body condition 
score and its association with dairy cow productivity, health and welfare. Journal of Dairy Science 92, 5769-5801.

Rukkwamsuk T., Wensing T., Geelen M.J.H. (1998). Effect of overfeeding during the dry period on regulation of adipose tissue metabolism in dairy cows during the periparturient period. Journal of Dairy Science 81, 2904-2911.

Rukkwamsuk T., Kruip T.A.M., Wensing T. (1999a). Relationship between overfeeding and overconditioning in the dry period and the problems of high producing dairy cows during the postparturient period. The Veterinary Quarterly 21, 71-77.

Rukkwamsuk T., Wensing T., Geelen M.J.H. (1999b). Effect of fatty liver on hepatic gluconeogenesis in periparturient dairy cows. Journal of Dairy Science 82, 500-505.

Sadri H., Bruckmaier R.M., Rahmani H.R., Ghorbani G.R., Morel I., van Dorland H.A. (2010). Gene expression of tumor necrosis factor and insulin signaling-related factors in subcutaneous adipose tissue during the dry period and early lactation in dairy cows. Journal of Animal Physiology and Animal Nutrition 94, 194-202.

Scheen A.J. (2003). Pathophysiology of type 2 diabetes. Acta Clinica Belgica 58-6, 335-341.

Schoenberg K.M., Perfield K.L., Farney J.K., Bradford B.J., Overton T.R. (2011). Prepartum 2,4-thiazolidinedione administration increases plasma tumor necrosis factor alpha in transition dairy cows. Journal of Dairy Science 94, Esuppl. 1.

Schröder U.J., Staufenbiel R. (2006). Invited review: Methods to determine body fat reserves in the dairy cow with special regard to ultrasonographic measurement of backfat thickness. Journal of Dairy Science 89, 1-14.

Shi H., Kokoeva M.V., Inouye K., Tzameli I., Yin H., Flier J.S. (2006). TLR4 links innate immunity and fatty acid-induced insulin resistance. The Journal of Clinical Investigation 116, 3015-3025.
Smith A.G., Sheridan P.A., Harp J.B., Beck M.A. (2007). Diet-induced obese mice have increased mortality and altered immune responses when infected with Influenza virus. The Journal of Nutrition 137, 1236-1243.

Sordillo L.M., Aitken S.L. (2009). Impact of oxidative stress on the health and immune function of dairy cattle. Veterinary Immunology and Immunopathology 128, 104-119.

Trayhurn P., Wood I.S. (2005). Signalling role of adipose tissue: adipokines and inflammation in obesity. Biochemical Society Transactions 33, 1078-1081.

Van Eetvelde M., De Smet S., Opsomer G. (2011). Measuring body energy reserves stored as fat in high yielding dairy cows. Vlaams Diergeneeskundig Tijdschrift 80, 3137.

Van Epps-Fung M., Williford J., Wells A., Hardy R.W. (1997). Fatty acid-induced insulin resistance in adipocytes. Endocrinology 138, 4338-4345.

World Health Organization. (2011). Cited on 28 September 2011. Fact sheet number 311. http://www.who.int/mediacentre/factsheets/fs311/en/index.html\#.

Wozniak S.E., Gee L.L., Wachtel M.S., Frezza E.E. (2009). Adipose tissue: the new endocrine organ? A review article. Digestive Diseases and Sciences 54, 1847-1856.

Wright I.A., Russel A.J.F. (1984). Partition of fat, body composition and body condition score in mature cows. Journal of Animal Production 38, 23-32.

Zoran D.L. (2010). Obesity in dogs and cats: a metabolic and endocrine disorder. The Veterinary Clinics of North America. Small Animal Practice 40, 221-239.

\section{Typisch testosteron}

Aart de Kruif schrijft in zijn boek 'Typisch testosteron" over de invloed van testosteron op het gedrag van mannen en vrouwen.

Hij stelt dat die invloed vele malen groter is dan we vermoeden. Door zijn onderzoek en kennis van het gedrag bij dieren raakte hij gefascineerd door de grote overeenkomsten tussen dierlijk en menselijk gedrag, met name wat de werking betreft van dit ene hormoon. Hij stelt op basis van wetenschappelijk onderzoek dat biologische factoren, zoals hormonen, vaak een veel sterker effect hebben op gedrag dan sociologische of culturele factoren. Hij neemt daarbij een duidelijk, voor sommigen misschien controversieel, standpunt in.

Lang vóór zijn geboorte is bepaald of een man met een hoog of laag testosterongehalte door het leven zal gaan. Mannen met een hoog testosterongehalte hebben een hoger libido, ze zijn dominanter en hebben meer energie. Mannen met een lagere testosteronconcentratie zijn socialer en meer teamplayers.

In dit zeer interessante boek is alles over de impact van testosteron verzameld; het genot, de noodzaak en de nadelen. Zonder testosteron geen vooruitgang, maar waarschijnlijk ook geen oorlogen en veel minder criminaliteit, aldus Aart de Kruif.

Kortom, een boek dat iedereen zou moeten lezen.

Nadia Eeckhout 